\title{
The spatial distribution of probable maximum precipitation (PMP) over the Kielce Upland in one day and multi-day intervals
}

\author{
Roman Suligowski \\ Jan Kochanowski University in Kielce, Institute of Geography, Świętokrzyska Street 15, 25-406 Kielce, \\ e-mail: rsulig@ujk.kielce.pl
}

\begin{abstract}
This paper presents an attempt to estimate the value of Probable Maximum Precipitation (PMP) over the Kielce Upland for one-day and multi-day intervals. Statistical methods were employed in the calculations. Precipitation data were obtained from 23 gauging stations. A regional frequency factor km (from Hershfield's formula) was calculated for each station based on a series of maximum annual precipitation totals from 1961 to 2006. The calculated PMP values range from $120.7 \mathrm{~mm}$ to $228.4 \mathrm{~mm}$ (within the 1-day precipitation group), from $140.7 \mathrm{~mm}$ to $266.3 \mathrm{~mm}$ (2-day group), from $158.9 \mathrm{~mm}$ to $294.1 \mathrm{~mm}$ (3-day group), and from $175.2 \mathrm{~mm}$ to $294.8 \mathrm{~mm}$ (4-day group). These values became reference values used to show the spatial distribution of PMP throughout the Kielce Upland region.
\end{abstract}

Key words: Probable Maximum Precipitation (PMP), Kielce Upland, Hershfield's method.

Submitted 8 August 2013, received 20 November 2013, accepted 7 January 2014

\section{Introduction}

According to the currently valid water law (Official Journal of the Republic of Poland 2012), the aims of water resource management are: satisfying the needs of society and the economy; protection of water and the natural environment. The determination of Probable Maximum Precipitation (PMP) values is especially important in catchments where the identification of a Probable Maximum Flood (PMF) stage is a necessity. This is normally the case when hydraulic structures are being planned for a particular section of a river. PMP is defined as the theoretically greatest depth of precipitation that is physically possible in a given time interval (minute, hour, day, etc.) over a particular area and geographic location at a given time of the year (Swain et al. 2006, WMO 2009, 2011).

The literature describes different techniques that can be used to determine the numerical value of PMP in different parts of the world (i.a. Hansen et al. 1982, Foufoula-Georgiou 1989, BOM 1994, Collier, Hardaker 1996, Svensson, Rakhecha 1998, Corrigan et al. 1999, Desa et al. 2001, Rakhecha, Clark 2002, Rezacova et al. 2005, Papalexiou, Koutsoyiannis 2006, Clark 2007, Desa, Rakhecha 2007, Casas et al. 2011). These techniques can be divided into two groups: 1) statistical analysis of precipitation frequency and 2) genetic analysis based on synoptic situations which have produced extremely heavy precipitation in the past. In Poland, research work in this field began at the turn of the 21st century (Suligowski 2005, 2009, 2010; Suligowski, Kupczyk 2006). Detailed meteorological and statistical analyses performed for catchments in southern Poland (Western Beskidy Mountains) set the stage for the definition of a modified version of PMP (Ozga-Zielińska et al. 2011).

In this work, an attempt has been made to determine PMP values using the statistical method for 1-day, 2-day, 3-day, and 4-day intervals for gauging stations located throughout the Kielce Upland. A secondary goal has been to show the spatial distribution of PMP values in this geographic region.

The Kielce Upland is a physiographic macroregion which is part of the much larger Małopolska Upland. The area of the Kielce Upland is $6800 \mathrm{~km}^{2}$ (Kondracki 2011). To the west, it borders the Przedbórz Upland - a macroregion that is also a part of the Małopolska Upland. To the south, it borders the Niecka Nidzianska macro-region (Małopolska Upland). To the north, it borders the South Mazowsze Hills. Its eastern boundary is formed by the Vistula Valley, the Lublin Upland, and a section of the Vistula Plain (the Sandomierz Dell) (Fig. 1). The region of interest possesses a variety of landforms such as low and midsize rounded hills, flattened foothills in some places, as well as the Świętokrzyskie Mountains (Holy Cross Mts) right in the central part of the Upland, which rise to 611 meters above sea level. The region is drained by a network of rivers with a characteristic central "point" of origin. These rivers serve as tributaries to the following rivers: the Kamienna, the Czarna Nida, the Opatówka, the Koprzywianka, the Czarna Staszowska, and the Czarna Maleniecka. The northern part of the region is drained by the upstream sections of the Radomka and the Iłżanka rivers (Fig. 1).

The spatial distribution of annual atmospheric precipitation totals across the analyzed region is the result of westerly and northwesterly rain-bearing air flows that dominate the area. A distinct hypsometric rainfall gradient can be observed at gauging stations located in the western part of the research area. The average annual precipitation total (based on data from 1961-2000) is 620-680 mm in this region. In the Świętokrzyskie Mts., the mean annual rainfall average is over $800 \mathrm{~mm}$ (Town of Święty Krzyż - $826 \mathrm{~mm}$ ). Lower precipitation totals are observed on the southeastern side of this mountain range (Staszów - 
543 mm, Klimontów - 572 mm, Sandomierz - 568 mm) This is true regardless of the elevation of the given gauging station, which allows one to conclude that this is a case of a rain shadow where the leeward side of a mountain range receives less rain than the windward side. Likewise, low mean annual precipitation totals are recorded in the Iłża Foothills area (Osówka - 528 mm, Kurzacze - 575 mm). Work done by Kłysik (1985), Żarnowiecki (1991), Olszewski (1992) and other researchers has confirmed the individual climactic conditions of the Świętokrzyskie Mountains, which includes its precipitation relationships.

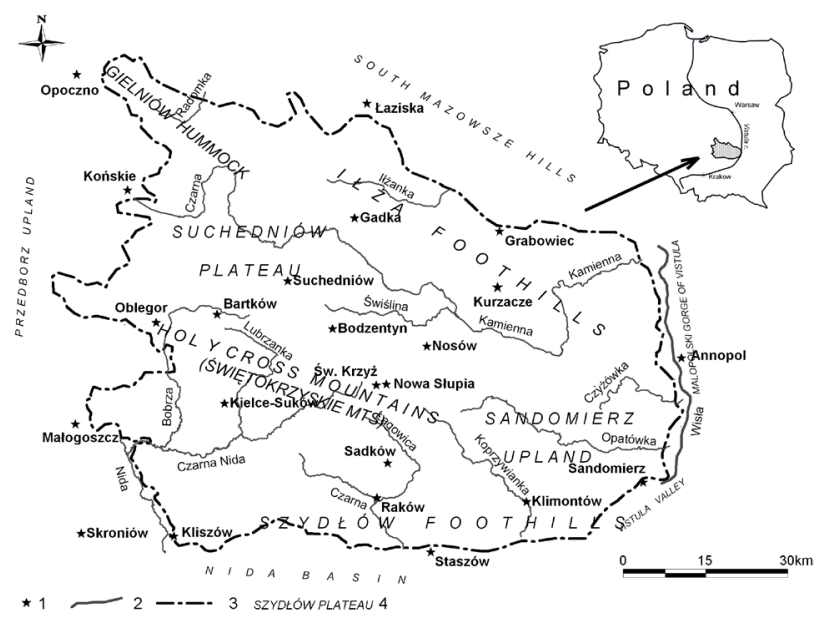

Figure 1. The research area and location of precipitation gauging stations ( 1 - precipitation station, 2 - river, 3 - boundaries of the Kielce Upland, 4 - the physiographic mesoregion

Precipitation during the summer season (May-October) constitutes a major portion of annual precipitation. Summer rainfall constitutes $60-62 \%$ of the annual total in the western part of the Upland while in the central and eastern parts, it reaches $66 \%$. July is the month of maximum precipitation. Finally, a autumn and spring precipitation quotient boundary runs across the region (Kożuchowski, Wibig 1988, Suligowski 1998).

\section{Material and methods}

The study is based on daily precipitation totals recorded during the summer season (May-October) at 23 gauging points at the Kielce Upland and its immediate vicinity (Fig. 1).

Changes in the Institute Meteorology and Water Management (IMGW) gauging network throughout the 20th century and gaps in archival materials made only the analysis of the period 1961-2006 possible. Data were obtained from the IMGW database. One-day as well as consecutive 2-day, 3-day, and 4-day maximum annual precipitation totals were compiled for each gauging point.

As precipitation at daily intervals is a non-continuous process, testing the homogeneity of precipitation series would require application of complicated statistical methods. In order to simplify the procedure of homogeneity analysis it was assumed that test of monthly precipita- tion sums sequences was sufficient for this purpose. This assumption made it possible to regard precipitation as a continuous process. To verify hypotheses of statistical homogeneity of monthly rainfall series, non-parametric Wilcoxon rank sum test (Hirsch et al. 1993) was applied. There was no temporal non-homogeneity detected in rainfall samples at significance level $\alpha=0.05$, though the data at the Kielce meteorological station could have been affected by the change of rain gauge location (to Suków, approximately $7 \mathrm{~km}$ south-west of Kielce). Also the calculated values t-statistic of Spearman's rank correlation coefficient test (Ozga-Zielińska, Brzeziński 1994) are lower than the critical values of the Student's t distribution at the assumed significance level $\alpha=0.05$. Undisturbed precipitation total homogeneity at the Kielce-Suków weather stations was likewise confirmed by research by Bogdanowicz, Stachy (1998) and Żarnowiecki, Szałach (2001). The analysis results suggest that there is no reason to reject the homogeneity hypothesis for the series analyzed. It can, therefore, be asserted with a high degree of certainty that all of the analyzed series are homogeneous - they originate from the same statistical population.

The procedure for calculating PMP when long data series are available can be found in the Manual for estimation of Probable Maximum Precipitation (WMO 2009). The procedure is based on the frequency equation (Hershfield 1965) in the following form:

$$
\mathrm{PMP}=\mathrm{P}_{\mathrm{n}}+\mathrm{k}_{\mathrm{m}} \mathrm{S}_{\mathrm{n}}
$$

where:

$\mathrm{P}_{\mathrm{n}}$ - mean annual maximum precipitation value,

$\mathrm{S}_{\mathrm{n}}$ - standard deviation of $\mathrm{nth}$ annual maximum precipitation series,

$\mathrm{k}_{\mathrm{m}}$ - frequency factor.

The frequency factor $\mathrm{k}_{\mathrm{m}}$ is a very important part of the equation as it constitutes the number of standard deviations added to the mean distribution value in order to attain the largest possible precipitation value within a series:

$$
\mathrm{P}_{\max }=\mathrm{P}_{\mathrm{n}-\mathrm{m}}+\mathrm{k}_{\mathrm{m}} \mathrm{S}_{\mathrm{n}-\mathrm{m}}
$$

hence:

$$
\mathrm{k}_{\mathrm{m}}=\frac{\mathrm{P}_{\max }-\mathrm{P}_{\mathrm{n}-\mathrm{m}}}{\mathrm{S}_{\mathrm{n}-\mathrm{m}}}
$$

$\mathrm{P}_{\mathrm{n}-\mathrm{m}}$ and $\mathrm{S}_{\mathrm{n}-\mathrm{m}}$ values are calculated in a standard manner, having first eliminated the maximum observed value from each data series obtained from every gauging station.

\section{Results}

Series of maximum one-day and multi-day precipitation totals recorded at each gauging station were characterized using basic statistics depicting their internal structure. A box and whisker plot was used for this purpose (Mitosek 2003) (Fig. 2). Such a plot allows for the analysis of the 


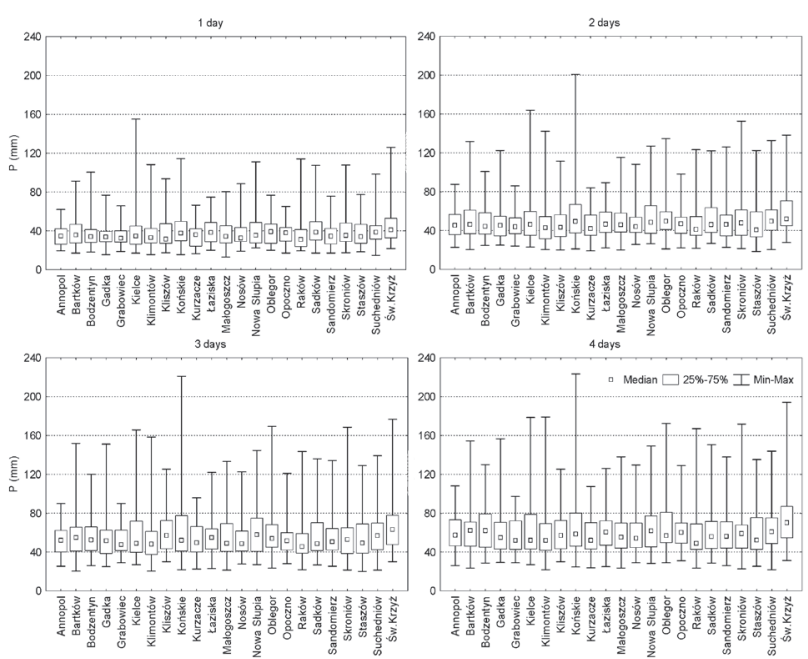

Figure 2. Basic statistics of maximum precipitation total series at the Kielce Upland

frequency distribution of maximum precipitation totals as well as their asymmetry and variability, the latter via a visual interpretation of the median, the lower and upper quartiles $(25 \%$ and $75 \%)$, the interquartile range, and extreme values.

A record one-day precipitation total, within the group of gauging stations of interest, was noted at the KielceSuków weather station in $2001(155.2 \mathrm{~mm})$. Precipitation values exceeding $100 \mathrm{~mm}$ per day were recorded at several gauging stations located, for the most part, in the Świętokrzyskie Mountains. It is important to add that storm cells were observed at the time, which resulted in extremely high precipitation levels at stations other than those included in the ongoing analysis. On 17th July 1967 in Mroczków (western edge of the Upland), an intense storm was observed producing $121.3 \mathrm{~mm}$ of precipitation in 1 hour and 45 minutes (24-hour total of $133.9 \mathrm{~mm}$ ) (Opady atmosferyczne 1968). Relatively low maximum daily precipitation totals - those under $70 \mathrm{~mm}$ - were observed at gauging stations in Grabowiec, Kurzacze (Iłżanka Foothills), and in Łaziska.

The highest precipitation totals in the region based on two consecutive 24-hour periods were recorded in 1970. Their maximum value was recorded at a gauging station in Końskie. On 17th and 18th July 1970, 200.9 mm of precipitation was recorded.

The largest relative increases in recorded maximum precipitation totals can be observed between a one 24hour period and a two 24-hour period. Differences between 3-day and 4-day totals are small (Fig. 2). Low 4-day precipitation totals are unusual, with only Grabowiec near Wąchock recording less than $100 \mathrm{~mm}$. The presence of maximum precipitation totals was associated with the movement of cool westerly or southwesterly fronts or large areas of low pressure towards the east (July 1970, August 1970, July 1997). Another potential reason was the flow of hot and humid tropical air from the Black Sea region and its convergence with polar marine air over the Kielce Upland (23-25 July 2001).

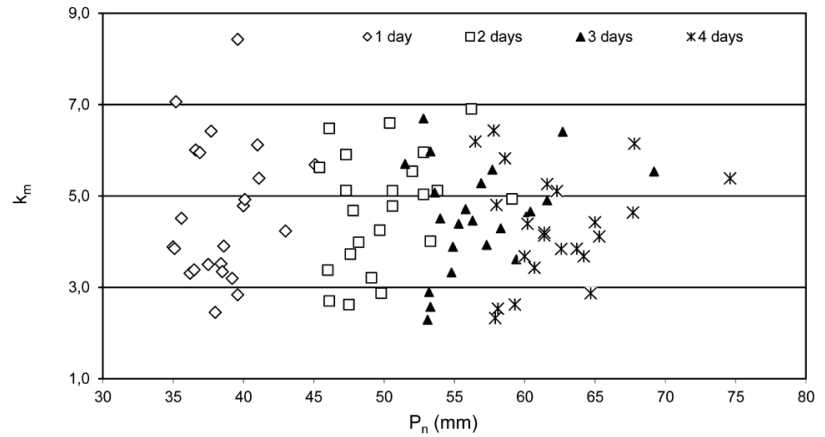

Figure 3. The scatterplot of points $\left(\mathrm{P}_{\mathrm{n}}, \mathrm{k}_{\mathrm{m}}\right)$ for the examined intervals

The calculated $\mathrm{km}$ values in the region of interest range independently of time interval from 2.29 to 8.42 (Fig. 3). The maximum 1-day $\mathrm{k}_{\mathrm{m}}$ (8.42) value was calculated based on data from the Kielce-Suków gauging station. The maximum 2-day $\mathrm{k}_{\mathrm{m}}$ (6.91) value came from Końskie. The maximum 3-day $\mathrm{k}_{\mathrm{m}}$ (6.69) value came from Gadka while the maximum 4-day $\mathrm{k}_{\mathrm{m}}$ (6.43) value came from Klimontów.

PMP calculations for each gauging station were performed based on the highest $\mathrm{k}_{\mathrm{m}}$ value within each given time interval at any of the stations in the region using Equation 1 (Tab. 1). The table shows a comparison of PMP values with maximum recorded precipitation totals. The highest one-day PMP value was calculated for the KielceSuków meteorological station - $228.4 \mathrm{~mm}$. This value is 1.5 times greater than the highest precipitation total recorded at this station. The highest multi-day values were calculated for the Końskie station (266.3 mm per 2 days, $294.1 \mathrm{~mm}$ per 3 days). There is a characteristic small increase in PMP when the time interval is lengthened from 3 to 4 days. Symptoms of this are decreasing PMP quotient values and the highest precipitation total recorded in history. The maximum calculated quotient is 2.3 for a 1 -day interval (Kurzacze), 1.9 for a 2-day interval, and 1.8 for 3-day and 4-day intervals (Tab. 1).
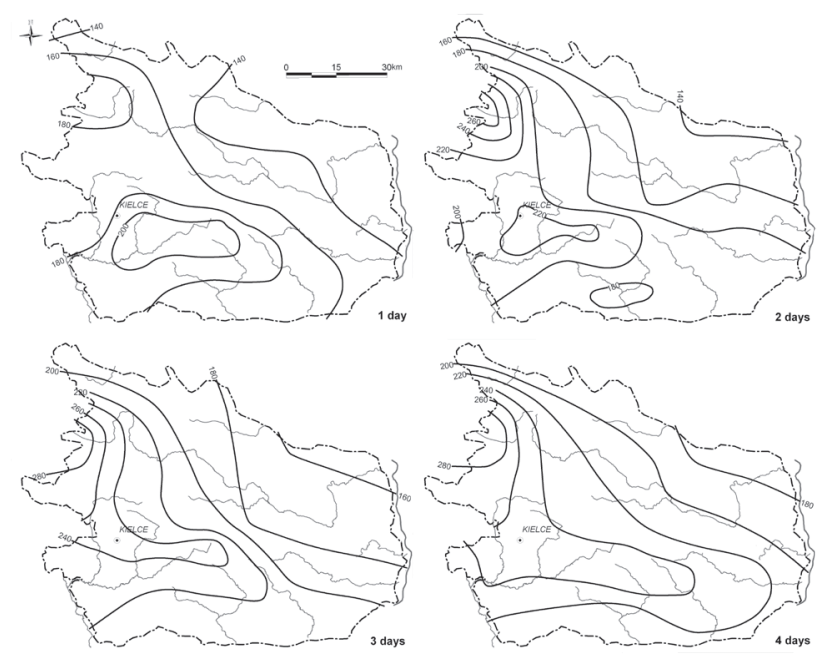

Figure 4. PMP (in mm) at the Kielce Upland

Maps of the spatial distribution of PMP point values at the Kielce Upland for the time intervals employed 
Table 1. PMP (in $\mathrm{mm}$ ) with respect to maximum observed precipitation totals $\left(\mathrm{P}_{\max }\right)$ for one-day and multi-day time intervals at the Kielce Upland

\begin{tabular}{|c|c|c|c|c|c|c|c|c|c|c|c|c|}
\hline \multirow{2}{*}{$\begin{array}{l}\text { pluviometric } \\
\text { stations }\end{array}$} & \multicolumn{3}{|c|}{1 day } & \multicolumn{3}{|c|}{ 2-days } & \multicolumn{3}{|c|}{ 3-days } & \multicolumn{3}{|c|}{ 4-days } \\
\hline & $\begin{array}{l}P_{\max } \\
(\mathrm{mm})\end{array}$ & $\begin{array}{l}\text { PMP } \\
(\mathrm{mm})\end{array}$ & $\begin{array}{l}\mathrm{PMP} / \\
\mathrm{P}_{\max }\end{array}$ & $\begin{array}{c}P_{\max } \\
(\mathrm{mm})\end{array}$ & $\begin{array}{l}\text { PMP } \\
(\mathrm{mm})\end{array}$ & $\begin{array}{l}\mathrm{PMP} / \\
\mathrm{P}_{\max }\end{array}$ & $\begin{array}{l}\text { Pmax } \\
(\mathrm{mm})\end{array}$ & $\begin{array}{l}\text { PMP } \\
(\mathrm{mm})\end{array}$ & $\begin{array}{l}\mathrm{PMP} / \\
\mathrm{P}_{\max }\end{array}$ & $\begin{array}{l}\text { Pmax } \\
(\mathrm{mm})\end{array}$ & $\begin{array}{l}\text { PMP } \\
(\mathrm{mm})\end{array}$ & $\begin{array}{l}\mathrm{PMP} / \\
\mathrm{P}_{\max }\end{array}$ \\
\hline Annopol & 62.0 & 129.0 & 2.1 & 87.6 & 158.0 & 1.8 & 90.0 & 165.4 & 1.8 & 108.0 & 182.1 & 1.7 \\
\hline Bartków & 91.3 & 171.7 & 1.9 & 131.8 & 202.8 & 1.5 & 152.0 & 233.7 & 1.5 & 154.6 & 241.0 & 1.6 \\
\hline Bodzentyn & 100.4 & 162.3 & 1.6 & 108.4 & 175.6 & 1.7 & 125.4 & 210.5 & 1.8 & 130.1 & 223.6 & 1.7 \\
\hline Gadka & 76.8 & 137.3 & 1.8 & 122.5 & 160.5 & 1.3 & 151.0 & 189.8 & 1.3 & 156.6 & 203.5 & 1.3 \\
\hline Grabowiec & 65.6 & 120.7 & 1.8 & 86.0 & 140.7 & 1.6 & 90.0 & 158.9 & 1.8 & 97.2 & 175.2 & 1.8 \\
\hline Kielce-Suków & 155.2 & 228.4 & 1.5 & 163.9 & 224.4 & 1.4 & 165.9 & 241.0 & 1.5 & 178.5 & 246.0 & 1.4 \\
\hline Klimontów & 108.3 & 173.8 & 1.6 & 142.2 & 197.4 & 1.4 & 158.5 & 213.5 & 1.3 & 179.0 & 228.1 & 1.3 \\
\hline Kliszów & 93.5 & 189.1 & 2.0 & 111.6 & 194.0 & 1.7 & 121.7 & 202.9 & 1.7 & 125.3 & 203.3 & 1.6 \\
\hline Końskie & 114.3 & 194.6 & 1.7 & 200.9 & 266.3 & 1.3 & 220.9 & 294.1 & 1.3 & 223.3 & 294.8 & 1.3 \\
\hline Kurzacze & 66.6 & 153.9 & 2.3 & 84.0 & 159.0 & 1.9 & 96.0 & 175.3 & 1.8 & 107.6 & 197.4 & 1.8 \\
\hline Łaziska & 74.8 & 145.3 & 1.9 & 89.4 & 159.0 & 1.8 & 122.1 & 180.2 & 1.5 & 126.0 & 191.3 & 1.5 \\
\hline Małogoszcz & 80.4 & 155.3 & 1.9 & 115.4 & 197.4 & 1.7 & 133.3 & 221.9 & 1.7 & 138.1 & 228.7 & 1.7 \\
\hline Nosów & 88.5 & 154.0 & 1.7 & 108.3 & 159.7 & 1.5 & 122.7 & 179.1 & 1.5 & 129.7 & 186.4 & 1.4 \\
\hline Nowa Słupia & 111.0 & 182.9 & 1.6 & 127.1 & 201.9 & 1.6 & 144.7 & 232.8 & 1.6 & 149.2 & 235.0 & 1.6 \\
\hline Oblęgor & 76.7 & 151.4 & 2.0 & 134.6 & 206.2 & 1.5 & 169.4 & 263.0 & 1.6 & 172.3 & 265.2 & 1.5 \\
\hline Opoczno & 65.2 & 138.8 & 2.1 & 98.2 & 156.0 & 1.6 & 120.9 & 175.0 & 1.4 & 129.1 & 184.1 & 1.4 \\
\hline Raków & 114.2 & 170.6 & 1.5 & 123.2 & 174.1 & 1.4 & 143.6 & 195.0 & 1.4 & 167.1 & 214.6 & 1.3 \\
\hline Sadków & 107.4 & 196.0 & 1.8 & 122.1 & 200.3 & 1.6 & 135.9 & 224.0 & 1.6 & 150.6 & 240.5 & 1.6 \\
\hline Sandomierz & 75.6 & 143.2 & 1.9 & 125.9 & 197.9 & 1.6 & 134.2 & 200.7 & 1.5 & 137.9 & 211.2 & 1.5 \\
\hline Skroniów & 107.7 & 190.6 & 1.8 & 152.5 & 219.6 & 1.4 & 168.5 & 235.5 & 1.4 & 171.8 & 240.8 & 1.4 \\
\hline Staszów & 77.2 & 167.5 & 2.2 & 122.5 & 183.7 & 1.5 & 129.0 & 208.6 & 1.6 & 135.2 & 219.4 & 1.6 \\
\hline Suchedniów & 98.4 & 165.2 & 1.7 & 132.7 & 193.3 & 1.5 & 139.2 & 220.2 & 1.6 & 143.8 & 226.7 & 1.6 \\
\hline Święty Krzyż & 126.0 & 204.0 & 1.6 & 138.3 & 212.2 & 1.5 & 176.5 & 253.3 & 1.4 & 194.2 & 259.8 & 1.3 \\
\hline
\end{tabular}

(Fig. 4). In general, the highest one-day PMP values were calculated for gauging stations located in the upper parts of the Upland (the Świętokrzyskie Mts.), where they exceed $200 \mathrm{~mm}$, and decrease towards the fringes of this region. The lowest PMP values were calculated for the Sandomierz Upland and the Iłżanka Foothills - the eastern and northeastern parts of the region. There is little spatial variability in PMP for multi-day time intervals. There is, however, a clear center of maximum PMP in the western part of the Kielce Upland with PMP exceeding $260 \mathrm{~mm}$ per 3-days (Fig. 4).

\section{Discussion}

The calculated values of the frequency factor $\mathrm{k}_{\mathrm{m}}$ are decidedly lower than those calculated for identical time intervals in the United States and Canada $\left(\mathrm{k}_{\mathrm{m}(\max )}=25\right)$ (WMO 2009) or in the Indian Subcontinent and China $\left(\mathrm{k}_{\mathrm{m}(\max )}=19\right)$ (Feng, He 1987). The values just mentioned from the North America and China are indeed, exceedingly high yielding unrealistic PMP values. The calculated $\mathrm{k}_{\mathrm{m}}$ values in this study correspond to values obtained in the Western Beskidy Mountain region (Suligowski 2005, Ozga-Zielińska et al. 2011). They are, however, much lo- wer than those in the Kłodzko Basin, especially for multiday time intervals (Suligowski, Kupczyk 2006). It is quite interesting that similar one-day $\mathrm{k}_{\mathrm{m}}$ values have been calculated for weather stations located in the southern part of the Malay Peninsula (Desa et al. 2001, Desa, Rakhecha 2007). The Malay Peninsula is characterized by a humid equatorial climate with a low coefficient of variation for series of maximum annual daily precipitation totals.

The successive decreases in maximum $\mathrm{k}_{\mathrm{m}}$ values with lengthening multi-day precipitation total time intervals at gauging stations at the Kielce Upland, thus far not observed in other areas, indicate a relative equalization of mean precipitation totals and their deviations relative to their counterparts located in the Kłodzko Basin, for example. This indicates that such extremely high multi-day precipitation totals, clearly deviating from multi-year means, are rather rare in the region of interest.

The results of this analysis made it possible to show the spatial variability of one-day and multi-day PMP values. The highest PMP values $\left(\mathrm{PMP}_{1-\text { day }}>200 \mathrm{~mm} /\right.$ day $)$ tend to be found at higher elevations encompassing the physiographic mesoregion of the Świętokrzyskie Mountains. In the case of multi-day precipitation totals, there exists a second center of high PMP values which encompasses 
the western fringes of the Upland. Low PMP values are found in the eastern (Sandomierz Upland) and northern (Iłżanka Foothills) parts of the region of interest.

The PMP values obtained for the Kielce Upland are lower than those calculated using a similar method for gauging stations in the Eastern Sudety Mountains and the Western Beskidy Mountains. The smallest differences are observed for one-day time intervals (Kielce-Suków - PMP $=228.4 \mathrm{~mm}$, Podzamek in the Sudety Mountains - PMP $=263.5 \mathrm{~mm}$, Ustroń Równica Wieś in the Beskidy Mountains - PMP $=300.1 \mathrm{~mm}$ ). These differences grow when longer observation periods are considered. The maximum probable 4-day precipitation at the Kielce Upland (Końskie $-\mathrm{PMP}=294.8 \mathrm{~mm}$ ) is over two times smaller than that calculated for southwestern Poland (Nowy Gierałtów $\mathrm{PMP}=597.9 \mathrm{~mm})$ or that for the Żywiec-area Beskidy Mountains (Szczyrk - PMP $=541.6 \mathrm{~mm}$ ).

The PMP point values calculated herein, when converted to a catchment scale with a defined surface area, can be used in rainfall-runoff transformations.

\section{Acknowledgments}

The work was supported by grant N306 056 32/3608 from the Ministry of Science and Higher Education).

\section{Bibliography}

Bogdanowicz, E., Stachý J., 1998, Maksymalne opady deszczu w Polsce. Charakterystyki projektowe, Seria Hydrologia i Oceanologia, Instytut Meteorologii i Gospodarki Wodnej, $23,85 \mathrm{pp}$

BOM (Bureau of Meteorology), 1994, The estimation of PMP in Australia: Generalised Short-Duration Method (GSDM), Australian Government, Bulletin 53, Canberra, 34 pp

Casas M.C., Rodríguez R., Prohom M., Gázquez A., Redaño A., 2011, Estimation of the Probable Maximum Precipitation in Barcelona (Spain), International Journal of Climatology, 31, 1322-1327, DOI:10.1002/joc. 2149

Clark C., 2007, New estimates of Probable Maximum Precipitation in South West England, Meterorological Applications, 2, 307-312, DOI:10.1002/met.5060020403

Collier C.G., Hardaker P.J., 1996, Estimating Probable Maximum Precipitation using a storm model approach, Journal of Hydrology, 183, 277-306, DOI:10.1016/0022-1694(95)02953-2

Corrigan P., Fenn D.D., Kluck D.R., Vogel J.L., 1999, Probable Maximum Precipitation for California, Hydrometeorological Report No. 59, Silver Spring, 392 pp

Desa M., Rakhecha P.R., 2007, Probable Maximum Precipitation for 24-h duration over an equatorial region: Part 2-Johor, Malaysia, Atmospheric Research, 84 (1), 84-90, DOI:10.1016/j. atmosres.2006.06.005

Desa M., Noriah A.B., Rakhecha P.R., 2001, Probable Maximum Precipitation for 24-hr duration over southeast asian monsoon region - Selangor, Malaysia, Atmospheric Research, 58 (1), 41-54, DOI:10.1016/S0169-8095(01)00070-9

Feng Y., He C.C., 1987, A study of the relationship between storm rainfall and flood based on analysis of the "83.7" flood at Ankang in the Han River Basin, Journal of Hydrology, 96 (1-4), 355-363, DOI:10.1016/0022-1694(87)90165-X

Foufoula-Georgiou E., 1989, A probabilistic storm transposition approach for estimating exceedance probabilities of extreme precipitation depths, Water Resources Research, 25 (5), 799815, DOI:10.1029/WR025i005p00799

Hansen E.M., Schreiner L.C., Miller J. F., 1982, Application of Probable Maximum Precipitation estimates: United States East of the 105th meridian, Hydrometeorological Report No. 52, Silver Spring, $268 \mathrm{pp}$

Hershfield D.M., 1965, Method for estimating Probable Maximum Precipitation, Journal of American Water Works Association, 57 (8), 965-972

Hirsch R.M., Heisel D.R., Cohn T.A., Gilroy E.J., 1993, Statistical analysis of hydrologic data, in: Handbook of hydrology, (ed. D.R. Maidment), chapter 17, McGraw-Hill, New York.

Kłysik K., 1985, Wpływ struktury termiczno-wilgotnościowej przyziemnych warstw powietrza na klimat lokalny w wybranych warunkach terenowych, Acta Geographica Lodziensia, 49, 119 pp

Kondracki J., 2011, Geografia regionalna Polski, PWN, Warszawa, $444 \mathrm{pp}$

Kożuchowski K., Wibig J., 1988, Kontynentalizm pluwialny w Polsce, zróżnicowanie geograficzne i zmiany wieloletnie, Acta Geographica Lodziensia, 55, 102 pp

Mitosek H.T., 2003, Problemy hydrologii stochastycznej. Procesy stochastyczne, pola losowe i momenty liniowe, Wydawnictwo Akademii Świętokrzyskiej, Kielce, 183 pp

Olszewski J.L., 1992, Indywidualizm klimatyczny Gór Świętokrzyskich, Rocznik Świętokrzyski, 19, 153-165

Ozga-Zielińska M., Brzeziński J., 2011, Hydrologia stosowana, PWN, Warszawa, $324 \mathrm{pp}$

Ozga-Zielińska M., Kupczyk E., Ozga-Zieliński B., Suligowski R., Niedbała J., Brzeziński J., 2011, River-flooding potential in terms of water structures safety and flooding hazard. Introduction to methodology, Institute of Meteorology and Water Management - National Research Institute, Warsaw, 90 pp

Papalexiou S.M., Koutsoyiannis D., 2006, A probabilistic approach to the concept of Probable Maximum Precipitation, Advances in Geosciences, EGU, 7, 51-54

Rakhecha P.R., Clark C., 2002, Areal PMP distribution of oneday to three-day duration over India, Meteorological Applications, 9, 399-406, DOI:10.1017/S1350482702004024

Rezacova D., Pesice P., Sokol Z., 2005, An estimation of the Probable Maximum Precipitation for river basins in the Czech Republic, Atmospheric Research, 77 (1-4), 407-421, DOI: 10.1016/j.atmosres.2004.10.011

Suligowski R., 1998, Reżim pluwialny dorzecza Nidy, Kieleckie Studia Geograficzne, 6, 71-84

Suligowski R., 2005, Maksymalny prawdopodobny opad deszczu w zlewni rzecznej na przykładzie zlewni Soły, in: Ekstremalne zjawiska hydrologiczne i meteorologiczne (ed. E. Bogdanowicz, U. Kossowska-Cezak, J. Szkutnicki), Monografie IMGW, 153-166

Suligowski R., 2009, Czasowe zróżnicowanie maksymalnego wiarygodnego opadu w zlewniach rzecznych Gór Świętokrzyskich, in: Zasoby i ochrona wód. Obieg wody 
i materii w zlewniach rzecznych (ed. R. Bogdanowicz, J. Fac-Beneda), Fundacja Rozwoju Uniwersytetu Gdańskiego, 325-328

Suligowski R., 2010, Maksymalny prawdopodobny opad deszczu w zlewni Czarnej Nidy (Wyżyna Kielecka), in: Hydrologia w inżynierii i gospodarce wodnej (ed. B. Więzik), Monografie Komitetu Inżynierii Środowiska PAN, 1 (68), 187-198

Suligowski R., Kupczyk E., 2006, Maksymalny wiarygodny opad w Kotlinie Kłodzkiej. Ocena na przykładzie zlewni Nysy Kłodzkiej, Zeszyty Naukowe AR Wrocław, Inżynieria Środowiska, 15, 289-302

Svensson C., Rakhecha P.R., 1998, Estimation of Probable Maximum Precipitation for dams in the Hongru River catchment, China, Theoretical and Applied Climatology, 59, 79-91
Swain R.E., England J.F. Jr., Bullard K.L., Raff D.A., 2006, Guidelines for Evaluating Hydrologic Hazards, Bureau of Reclamation, Denver, 83 pp

WMO (World Meteorological Organisation), 2009, Manual for estimation of Probable Maximum Precipitation, WMO No. 1045 , Geneva, $259 \mathrm{pp}$

WMO (World Meteorological Organisation), 2011, Guide to climatological practices. Weather, Climate, Water, No. 100, Geneva, $117 \mathrm{pp}$

Żarnowiecki G., 1991, Opady atmosferyczne Wyżyny Środkowomałopolskiej, Studia Kieleckie, 2/70, 47-62

Żarnowiecki G., Szałach G., 2001, Wpływ przeniesienia stacji meteorologicznej Kielce na jednorodność serii obserwacyjnych, Annales UMCS Lublin, Sectio B, 49, 413-418 